\title{
Water vapor and CMAS corrosion tests of Si/Y2SiO5 Thermal and Environmental Barrier Coating
}

\section{Qi Zhang}

Beijing Institute of Technology

\section{Xueqin Zhang}

Beijing Institute of Technology

\section{Zhuang Ma}

Beijing Institute of Technology

Ling Liu ( $\nabla$ richrad@bit.edu.cn )

Beijing Institute of Technology https://orcid.org/0000-0001-5926-7058

Yanbo Liu

Beijing Institute of Technology

Wei Zheng

Beijing Institute of Technology

\section{Research Article}

Keywords: thermal and environmental barrier coating, Y2SiO5 rare earth silicate, water vapor corrosion, CMAS corrosion

Posted Date: September 20th, 2021

DOl: https://doi.org/10.21203/rs.3.rs-889492/v1

License: (c) (i) This work is licensed under a Creative Commons Attribution 4.0 International License.

Read Full License 


\title{
Water vapor and CMAS corrosion tests of $\mathrm{Si} / \mathrm{Y}_{2} \mathrm{SiO}_{5}$ thermal and
}

\section{environmental barrier coating}

\author{
Qi Zhang a,b, Xueqin Zhang a,b, Zhuang Ma ${ }^{\mathrm{a}, \mathrm{b}}$, Ling Liu ${ }^{\mathrm{a}, \mathrm{b} *}$, Yanbo Liu ${ }^{\mathrm{a}, \mathrm{b}}$, Wei Zheng ${ }^{\mathrm{a}}$ \\ ${ }^{a}$ School of Materials Science and Engineering, Beijing Institute of Technology, Beijing 100081, \\ China
}

${ }^{b}$ Beijing Institute of Technology Chongqing Innovation Center, Chongqing 401120, China

\section{Abstract}

Thermal and environmental barrier coating (TEBC), the up-to-date concept, is introduced to protect silicon-based ceramics matrix composites (CMC) from not only high temperature water vapor but also the alkali salt from volcanic ash and dust suspending in atmosphere. Because both of high temperature steam and CMAS will make Si-based CMC deteriorate rapidly. By executing the corrosion test against high temperature water vapor, we find that $\mathrm{Si} / \mathrm{Y}_{2} \mathrm{SiO}_{5}$ double-layer TEBC can effectively protect $\mathrm{SiC}_{\mathrm{f}} / \mathrm{SiC} \mathrm{CMC}$ from water vapor at $1300{ }^{\circ} \mathrm{C}$ for over 205 hours. Almost all $\mathrm{Y}_{2} \mathrm{SiO}_{5}$ transform into $\mathrm{Y}_{4.67}\left(\mathrm{SiO}_{4}\right)_{3} \mathrm{O}$ after corrosion test. It is also found that in CMAS corrosion test, the reaction zone formed between CMAS and $\mathrm{Y}_{2} \mathrm{SiO}_{5}$ layer prevents the mutual diffusion of elements in CMAS and $\mathrm{Y}_{2} \mathrm{SiO}_{5}$ layer. The apparent activation energy of reaction between CMAS and $\mathrm{Y}_{2} \mathrm{SiO}_{5}$ in $1200 \sim 1300^{\circ} \mathrm{C}$ temperature ranges is calculated to be $713.749 \mathrm{~kJ} / \mathrm{mol}$. These findings provide a reference to select appropriate materials for TEBC.

Key words: thermal and environmental barrier coating, $\mathrm{Y}_{2} \mathrm{SiO}_{5}$ rare earth silicate, water vapor corrosion, CMAS corrosion

\footnotetext{
* corresponding author at: School of Materials Science and Engineering, Beijing Institute of Technology, Beijing 100081, PR China.

E-mail: L. Liu, richard@bit.edu.cn.
} 


\section{Introduction}

In order to further develop the high thrust-weight ratio aero engine, decreasing the weight of ho section structural components and improving the inlet temperature of combustion room simultaneously is the most efficient approach[1]. Nickle-based high temperature alloy is used as the hot section structural materials in aero engine. However, the operating temperature in combustion room has already out of the usage temperature limit of the Ni-based alloy which restricts the further improvement of thrust-weight ratio. Si-based ceramics matrix composites (CMC) such as carbon fiberreinforced silicon carbide $\mathrm{CMC}\left(\mathrm{C}_{\mathrm{f}} / \mathrm{SiC} \mathrm{CMC}\right)$ and silicon carbide fiber-reinforced silicon carbide $\mathrm{CMC}\left(\mathrm{SiC}_{\mathrm{f}} / \mathrm{SiC} \mathrm{CMC}\right)$ are promising candidates for hot section structural components due to low density and exceptional thermo-mechanical stability and good oxidation resistance[2-4]. In dry air, Si-based CMC will react with oxygen to form the silica which can isolate the oxygen and prevent Si-based CMC not to be oxidize further. However, the operating environment of Si-based CMC is full of hot gas containing high temperature water vapor. The passive silica will react with water vapor to form volatile $\mathrm{Si}(\mathrm{OH})_{4}[5]$. The volatile $\mathrm{Si}(\mathrm{OH})_{4}$ can be easily brushed away by high pressure hot gas, making Si-based CMC continuously exposure to hot gas. Continuous corrosion from water vapor makes Si-based CMC deteriorate rapidly.

The environmental barrier coating (EBC) fabricated on the surface of Si-based CMC aims at protecting Si-based CMC from hot gas at first. The EBC is always made up by two or three layers of coatings containing top layer and bond layer. The materials used as top layer of EBC should satisfy some constraints. For example, excellent water vapor corrosion resistance is the most fundamental condition. The coefficient of thermal expansion (CTE) of materials should be as close to the CTE of Si-based CMC as possible to avoid cracking and delamination of coating. Besides, 
materials must be stable and compatible with bond layer so that deleterious reaction won't happen. The bond coating is deposited to alleviate the thermal mismatch between top layer and Si-based CMC resulting from the widely varying CTE between them. When oxygen permeating into coating along the cracks in top layer, the bond layer will consume oxygen and stop them continuously diffuse inward[6]. Over the past thirty years, researches about EBC have made great breakthrough. It has been proved that EBC effectively extends the service time of Si-based CMC [7]. The up-todate EBC system containing rare earth silicate top layer and silicon bond layer is proved to be the most excellent candidate.

Researches have shown that resistance against high temperature water vapor of monosilicates is much more excellent than that of rare earth disilicates[6]. Besides, there are at most seven types of crystal structures of one disilicate over the wide temperature range[8,9]. The CTE of different crystal structures varies greatly which has an adverse influence on the integrality of EBC. There are only two types of crystal structures of every monosilicates[8,9]. So, the monosilicate is much more suitable to be used as top layer of $\mathrm{EBC} . \mathrm{Y}_{2} \mathrm{SiO}_{5}$ is the most outstanding candidate out of many rare earth monosilicates due to its superior thermal and mechanical properties in high temperature condition[10-17]. The water vapor corrosion resistance of $\mathrm{Y}_{2} \mathrm{SiO}_{5}$ is also proved to be more excellent than other monosilicates from both experiments and simulated calculations[13-15].

The damage to Si-based CMC caused by high temperature water vapor can be alleviated through EBC as illustrated by several researches $[14,18,19]$. But Si-based CMC still faces the risk of corroded by foreign alkali salt. Foreign alkali salts will react with each other at high temperature to form the CMAS glass. CMAS can slowly permeate into the $\mathrm{SiO}_{2}$ thin layer on the surface of Si-based CMC, destroying the 
protection of $\mathrm{SiO}_{2}$ for Si-based CMC. The Si-based CMC itself can be operated in extremely high temperature, so in addition to high temperature water vapor, the EBC only need protect Si-based CMC against CMAS, justly like the role of TBC to Nibased alloy. And such thermal and environmental barrier coating (TEBC) is in urgent need[20]. However, most of researches only focus on the water vapor corrosion resistance of rare earth silicate. There is hardly any investigation about the resistance against the hot gas and CMAS simultaneously.

We deposited the $\mathrm{Si} / \mathrm{Y}_{2} \mathrm{SiO}_{5}$ double layers $\mathrm{TEBC}$ on $\mathrm{SiC}_{\mathrm{f}} / \mathrm{SiC}$ substrate by air plasma spraying (APS) technique. The high temperature resistance against water vapor and CMAS of $\mathrm{Si} / \mathrm{Y}_{2} \mathrm{SiO}_{5} \mathrm{TEBC}$ coatings were investigated. The corrosion behaviors and mechanisms were also discussed in detail.

\section{Materials and methods}

\subsection{Deposition of coatings}

The $\mathrm{Y}_{2} \mathrm{SiO}_{5}$ coating was deposited over the top of $\mathrm{SiC}_{\mathrm{f}} / \mathrm{SiC}$ composite substrates covered with silicon coating by air plasma spraying instrument (GTS-5500, Praxair, America) equipped with SG-100 spraying gun. The substrate used in the experiment was provided by Research Center of Composite Materials with the size of $17 \mathrm{~mm} \times 15$ $\mathrm{mm} \times 3 \mathrm{~mm}$. It is noticeable that when we purchased the substrates, the silicon coating with the thickness of $80 \mu \mathrm{m}$ had already been fabricated on the surface of $\mathrm{SiC}_{\mathrm{f}} / \mathrm{SiC}$ composite substrates.

The $\mathrm{Y}_{2} \mathrm{SiO}_{5}$ powders used for top coating were obtained by spraying granulation and calcining with purchased $\mathrm{Y}_{2} \mathrm{SiO}_{5}$ powders $(\geq 99.9 \%, 1-3 \mu \mathrm{m}$, Beijing Zhongjinyan New Material Technology Co.,Ltd., Beijing, China). The slurry used in spraying granulation was a mixture of $\mathrm{Y}_{2} \mathrm{SiO}_{5}$ powders (35 wt.\%), polyvinyl alcohol (PVA, 0.5 wt.\%), and deionized water. After spray granulation, the $\mathrm{Y}_{2} \mathrm{SiO}_{5}$ powders were 
calcined at $1100{ }^{\circ} \mathrm{C}$ in furnace to get rid of PVA and achieve the densification. The densified $\mathrm{Y}_{2} \mathrm{SiO}_{5}$ powders were sieved to obtain the spraying powders meeting the flowability required in APS process.

The $\mathrm{Y}_{2} \mathrm{SiO}_{5}$ coatings was deposited at room temperature. The thickness $\mathrm{Y}_{2} \mathrm{SiO}_{5}$ coatings was $120 \mu \mathrm{m}$, respectively. The substrate coated with silicon coating was ultrasonically cleaned in ethanol to keep the surface clean before coating deposition. The substrates were fixed on the steel wire gauze on the surface of steel shelf. The spraying parameters were shown in Table 1 . The moving rate during coating deposition is $0.5 \mathrm{~m} / \mathrm{s}$. After deposition, the coatings were annealing in Ar atmosphere at $1400^{\circ} \mathrm{C}$ to release the stress generated in preparing process. The $\mathrm{Si} / \mathrm{Y}_{2} \mathrm{SiO}_{5}$ coated substrates were then ultrasonic cleaned in ethanol for further test.

\begin{tabular}{|c|c|}
\hline Parameter & Value \\
\hline Spraying current (A) & 800 \\
\hline Primary gas (Ar) flow $\left(\mathrm{L} \mathrm{min}{ }^{-1}\right)$ & 40 \\
\hline Secondary gas $(\mathrm{He})$ flow $\left(\mathrm{L} \cdot \mathrm{min}^{-1}\right)$ & 14 \\
\hline Carrier gas (Ar) flow $\left(\mathrm{L} \mathrm{min}^{-1}\right)$ & 4.7 \\
\hline Powder feed rate (RPM) & 3.0 \\
\hline Spray distance (mm) & 80 \\
\hline
\end{tabular}

\subsection{Water vapor corrosion test}

Water vapor corrosion test of $\mathrm{Si} / \mathrm{Y}_{2} \mathrm{SiO}_{5}$ coated $\mathrm{SiC}_{\mathrm{f}} / \mathrm{SiC}$ substrates at elevated temperature was carried out in tube furnace (GSL-1600X, Hefei Kejing Material Technology Co., Ltd.). The test was performed at $1300{ }^{\circ} \mathrm{C}$ in $90 \% \mathrm{H}_{2} \mathrm{O} / 10 \% \mathrm{O}_{2}$ atmosphere on a 10-hour rotation. The gas generator (LVD-F1, Hefei Kejing Material 
Technology Co., Ltd.) was used to generate the vapor and the flow rate of steam was $0.17 \mathrm{~cm} / \mathrm{s}$. In order to accurately obtain the weight change tendency of samples during water vapor corrosion process, the samples on the alumina boat were taken out from the tube furnace and measured the weight of the sample every $10 \mathrm{~h}$.

\subsection{CMAS corrosion test}

The $38 \mathrm{CaO}-5 \mathrm{MgO}-8 \mathrm{AlO}_{1.5}-49 \mathrm{SiO}_{2}(\mathrm{CMAS})$ was used as corrosive medium to simulate practical situation of aero-energy in service. The CMAS powders were grinded and uniformly coated on the surface of coating and then heated to 1200,1250 and $1300{ }^{\circ} \mathrm{C}$ in furnace at a heating rate of $5^{\circ} \mathrm{C} / \mathrm{min}$ for $15,90,150$ and $240 \mathrm{~min}$. The CMAS powders used in this work were synthesized at $1550^{\circ} \mathrm{C}$ for $4 \mathrm{~h}$ with $\mathrm{CaO}$, $\mathrm{MgO}, \mathrm{Al}_{2} \mathrm{O}_{3}$ and $\mathrm{SiO}_{2}$ in a molar ratio of 38:5:4:49. The $\mathrm{CaO}$ and $\mathrm{Al}_{2} \mathrm{O}_{3}$ powders $(\mathrm{AR}$, 3-5 $\mu \mathrm{m}$, Shanghai, China) were provided by Shanghai Aladdin Biochemical Technology Co.,Ltd. The $\mathrm{MgO}$ and $\mathrm{SiO}_{2}$ powders (AR, 3-5 $\mu \mathrm{m}$, Beijing, China) were both provided by Sinopharm Chemical Reagent Beijing Co.,Ltd.

\subsection{Analysis and characterization}

The morphologies of coatings before and after corrosion and the elements distribution were observed by scanning electron microscope (SEM, Philips S-4800, Hitachi Ltd., Yokohama, Japan) with attached energy dispersive spectrometer (EDS). The SEM can also be used to measure the thickness of emerging layer between $\mathrm{Y}_{2} \mathrm{SiO}_{5}$ and silicon layer after corroding. The phases compositions of coating in different states were characterized by X-ray diffractometer (XRD, RIGAKU D/MaxrB, Rigaku International Corp., Tokyo, Japan). The scanning rate of XRD test was $5 \%$ min over the $2 \theta$ range of $10^{\circ}-90^{\circ}$. 


\section{Materials and Methods}

3.1 Comparison of $\mathrm{Si} / \mathrm{Y}_{2} \mathrm{SiO}_{5} \mathrm{TEBC}$ before and after water oxygen corrosion According to the weight change rule of $\mathrm{Si} / \mathrm{Y}_{2} \mathrm{SiO}_{5}$ coated $\mathrm{SiC}_{\mathrm{f}} / \mathrm{SiC}$ substrate corroded in $90 \% \mathrm{H}_{2} \mathrm{O} / 10 \% \mathrm{O}_{2}$ atmosphere at $1300^{\circ} \mathrm{C}$, it can be found that $\mathrm{Si} / \mathrm{Y}_{2} \mathrm{SiO}_{5}$ can persistently protect $\mathrm{SiC}_{\mathrm{f}} / \mathrm{SiC}$ substrate from high temperature water vapor for more than 193 hours. The maximum weight gain per unit area is less than $0.4 \mathrm{mg} / \mathrm{cm}^{2}$ throughout the whole corrosion test. In the initial stage of corrosion, there is slightly increase of weight per unit area. In the next few hours, the mass change versus time curve keeps flat without obvious fluctuation. The curve drops suddenly when accumulated corrosion time over 193 hours. The decline of mass change versus time curve can be attributed to the partly peeling off of $\mathrm{Si} / \mathrm{Y}_{2} \mathrm{SiO}_{5}$ coating. In our preexperiment, the mullite $/ \mathrm{Y}_{2} \mathrm{SiO}_{5} \mathrm{TEBC}$ system can only provide the protection for $\mathrm{SiC}_{\mathrm{f}} / \mathrm{SiC}$ substrate no more than 105 hours. The water vapor corrosion resistance of $\mathrm{Si} / \mathrm{Y}_{2} \mathrm{SiO}_{5}$ is also apparently excellent than $\mathrm{ZrSiO}_{4}$ coating[21]. The works mentioned above demonstrate $\mathrm{Si} / \mathrm{Y}_{2} \mathrm{SiO}_{5}$ TEBC system has great potential against high temperature water vapor.

The surface microstructure of $\mathrm{Si} / \mathrm{Y}_{2} \mathrm{SiO}_{5} \mathrm{TEBC}$ before and after water vapor corrosion in $90 \% \mathrm{H}_{2} \mathrm{O} / 10 \% \mathrm{O}_{2}$ atmosphere at $1300{ }^{\circ} \mathrm{C}$ are shown in Fig. 1. It can be seen clearly from Fig. 1(a) that before high temperature water vapor corrosion, the top photography $\mathrm{Y}_{2} \mathrm{SiO}_{5}$ layer is relatively flat. Almost all $\mathrm{Y}_{2} \mathrm{SiO}_{5}$ powders melt and spread well. After 205 hours' corrosion test, there are obvious corrosive traces on the topography of $\mathrm{Y}_{2} \mathrm{SiO}_{5}$ layer accompanying with several cracks as shown in Fig. 1(b) and Fig. 1(c). 

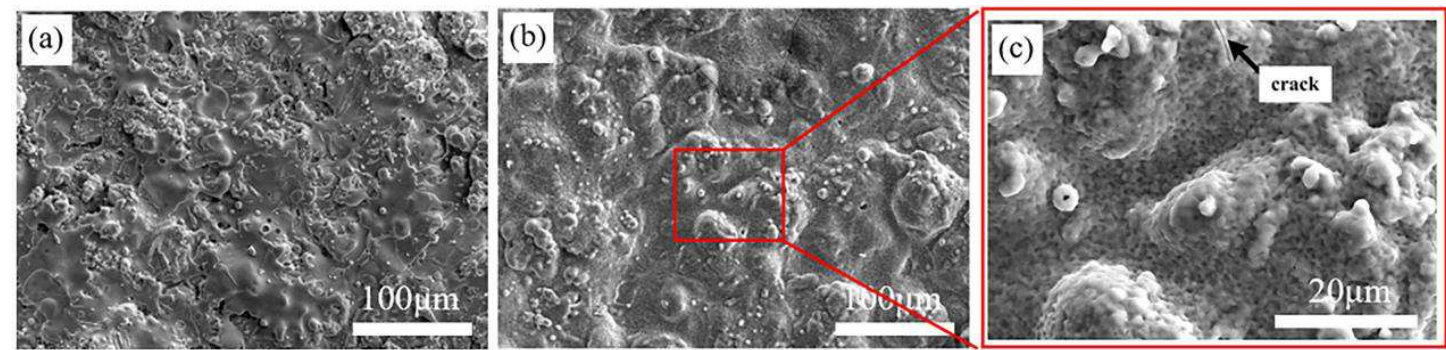

Fig. 1 Surface microstructure of $\mathrm{Si} / \mathrm{Y}_{2} \mathrm{SiO}_{5}$ TEBC (a) before and (b) after corrosion in $90 \% \mathrm{H}_{2} \mathrm{O} / 10 \% \mathrm{O}_{2}$ atmosphere at $1300{ }^{\circ} \mathrm{C}$, (c) magnification of (b)

The cross-section microstructure of $\mathrm{Si} / \mathrm{Y}_{2} \mathrm{SiO}_{5} \mathrm{TEBC}$ before and after water vapor corrosion are shown in Fig. 2. It can be seen from Fig. 2(a) that $\mathrm{Si} / \mathrm{Y}_{2} \mathrm{SiO}_{5} \mathrm{TEBC}$ before corrosion is dense without mud-cracks and large holes. The $\mathrm{Y}_{2} \mathrm{SiO}_{5}$ top layer combines Si bond layer well. The large area defect in Si bond coating is caused in sample making process by accident. After 205 hours' water vapor corrosion in $90 \% \mathrm{H}_{2} \mathrm{O} / 10 \% \mathrm{O}_{2}$ atmosphere at $1300{ }^{\circ} \mathrm{C}$, the width of micro cracks gets larger and the number of micro holes gets bigger. The EDS analysis result demonstrates that the emerging layer between top layer and bond layer after corrosion is thermal growing oxide (TGO).
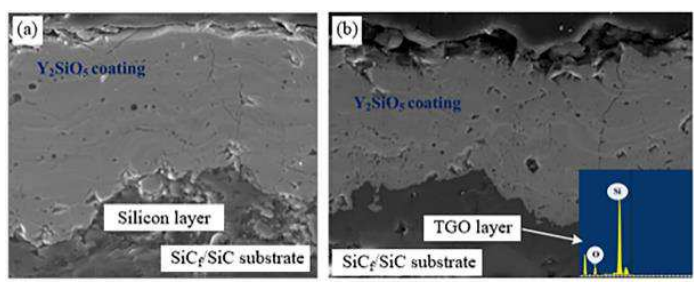

Fig. 2 Cross-section microstructure of $\mathrm{Si} / \mathrm{Y}_{2} \mathrm{SiO}_{5} \mathrm{TEBC}$ (a) before and (b) after corrosion in $90 \% \mathrm{H}_{2} \mathrm{O} / 10 \% \mathrm{O}_{2}$ atmosphere at $1300{ }^{\circ} \mathrm{C}$

The phases detected by XRD before and after water vapor corrosion test are shown in Fig. 3. The main phase in coating before corrosion is $\mathrm{Y}_{2} \mathrm{SiO}_{5}$. There is also a small amount of $\mathrm{Y}_{4.67}\left(\mathrm{SiO}_{4}\right)_{3} \mathrm{O}$ exists in coating. After corrosion test, the $\mathrm{Y}_{4.67}\left(\mathrm{SiO}_{4}\right)_{3} \mathrm{O}$ 
accounts for the vast majority of coating and the amount of $\mathrm{Y}_{2} \mathrm{SiO}_{5}$ significantly decreases compare with the phase composition of coating before corrosion.

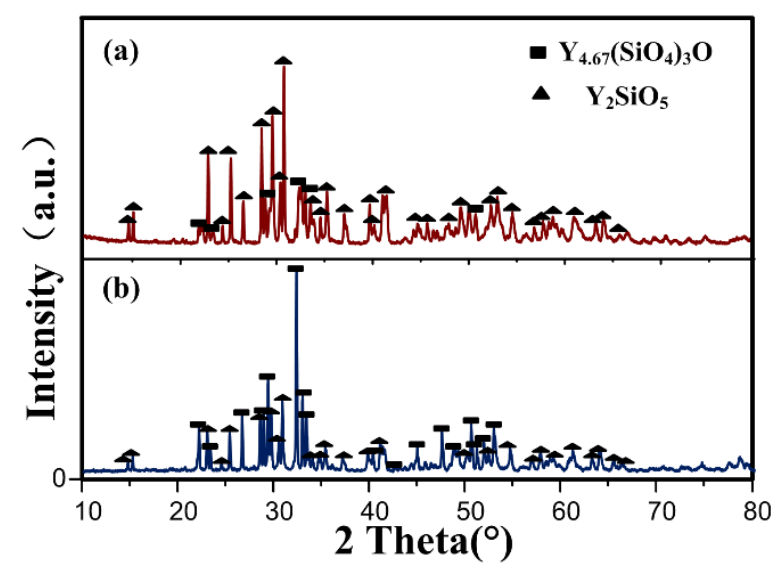

Fig. 3 Phase composition of $\mathrm{Si} / \mathrm{Y}_{2} \mathrm{SiO}_{5}$ TEBC (a) before and (b) after corrosion in $90 \% \mathrm{H}_{2} \mathrm{O} / 10 \% \mathrm{O}_{2}$ atmosphere at $1300{ }^{\circ} \mathrm{C}$

\subsection{Water vapor corrosion mechanism of $\mathrm{Si} / \mathrm{Y}_{2} \mathrm{SiO}_{5}$ coatings}

As depicted in Fig. 4(a), at early stage of water vapor corrosion test, the $\mathrm{Y}_{2} \mathrm{SiO}_{5}$ top layer keeps intact. There is almost no obvious defect on the surface and cross-section of coating. The $\mathrm{Y}_{2} \mathrm{SiO}_{5}$ top layer commendably protect bond layer and $\mathrm{SiC}_{\mathrm{f}} / \mathrm{SiC}$ substrate from high temperature water vapor so that there is only slightly weight gain at early stage of corrosion.
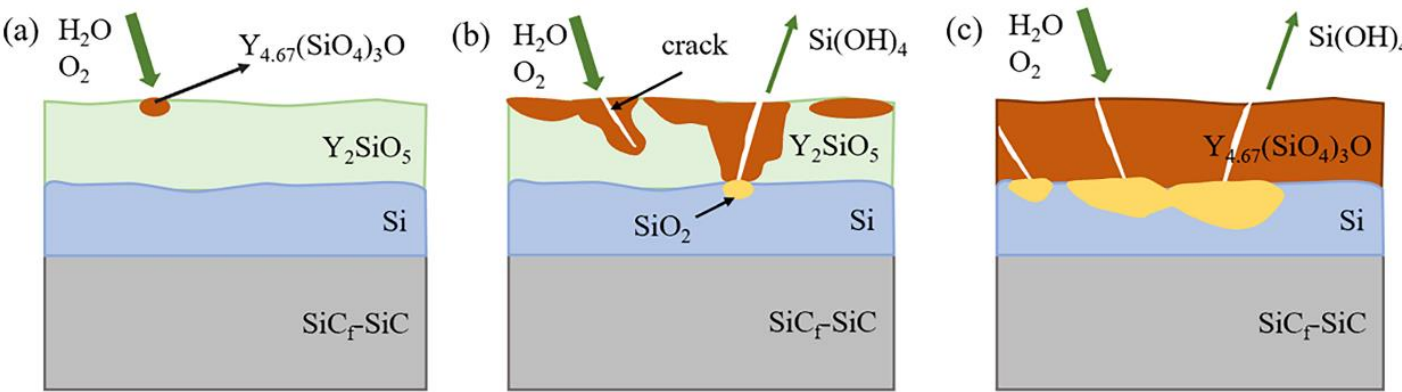

Fig. 4 Recession mechanism of $\mathrm{Si} / \mathrm{Y}_{2} \mathrm{SiO}_{5}$ TEBC corroded in water vapor environment at (a) initial, (b) middle and (c) late stage 
The $\mathrm{Si} / \mathrm{Y}_{2} \mathrm{SiO}_{5}$ coated $\mathrm{SiC}_{\mathrm{f}} / \mathrm{SiC}$ sample is taken out from tube furnace every 10 hours to measure the variation of weight and flaking condition. After measuring, the sample is put back into tube furnace for next testing rotation. The take-out and putback process during test accompany with great temperature change which will introduce great stress into $\mathrm{Si} / \mathrm{Y}_{2} \mathrm{SiO}_{5}$ TEBC due to the different CTE between $\mathrm{Y}_{2} \mathrm{SiO}_{5}$ top layer and bond layer. With the influence of stress, a small number of micro-cracks in $\mathrm{Y}_{2} \mathrm{SiO}_{5}$ top layer will get wider and longer. Besides, the new cracks initiate as test continuing. Although oxygen permeability in $\mathrm{Y}_{2} \mathrm{SiO}_{5}$ is low, there are still small amount of oxygen penetrate through the top layer in the form oxygen ion. The molecular oxygen can also arrive at the interface between top layer and bond layer along the generated cracks. The oxygen ion and the oxygen molecule will react with silicon bond layer, leading to the formation of silica. Silica is also known as TGO. Not only oxygen, but also water vapor can penetrate through the top layer along the cracks. The water vapor reacts with TGO to form the volatile $\mathrm{Si}(\mathrm{OH})_{4}$ as shown in Fig. 4(b). The weight gain caused by the oxidation of bond layer and the weight loss caused by the volatilization of $\mathrm{Si}(\mathrm{OH})_{4}$ cancel each other out. So, the mass change versus time curve still keeps flat without obvious fluctuation before accumulated corrosion time extending to 193 hours. In short, although extension of cracks and the corrosion of bond layer happen, there is little impact on the total function of $\mathrm{Si} / \mathrm{Y}_{2} \mathrm{SiO}_{5}$ coating. The $\mathrm{Si} / \mathrm{Y}_{2} \mathrm{SiO}_{5}$ still efficiently isolates the $\mathrm{SiC}_{\mathrm{f}} / \mathrm{SiC}$ substrate from water vapor.

When corrosion test continued for over 193 hours, the generated longitudinal and transverse cracks intersect with each other, forming a connected three-dimensional crack network. The high temperature water vapor and oxygen get much easier to arrive at the bond layer. The severer oxidation of bond layer and volatilization of 
$\mathrm{Si}(\mathrm{OH})_{4}$ happen which deteriorates the bonding strength between top layer and bond layer. Part of $\mathrm{Y}_{2} \mathrm{SiO}_{5}$ layer peels off under the influence of stress. So, the mass change verses time curve dramatically drops down when corrosion time extend to 205 hours. Besides, during the long period of corrosion test, $\mathrm{Y}_{2} \mathrm{SiO}_{5}$ react with $\mathrm{TGO}$ to form $\mathrm{Y}_{4.67}\left(\mathrm{SiO}_{4}\right)_{3} \mathrm{O}$ which is the reason why a large number of $\mathrm{Y}_{4.67}\left(\mathrm{SiO}_{4}\right)_{3} \mathrm{O}$ can be detected after corrosion test. So, as shown in Fig. 4(c) the proportion of $\mathrm{Y}_{2} \mathrm{SiO}_{5}$ decreases and the proportion of $\mathrm{Y}_{4.67}\left(\mathrm{SiO}_{4}\right)_{3} \mathrm{O}$ increases as the water vapor corrosion test continues.

\subsection{Changing of $\mathrm{Si} / \mathrm{Y}_{2} \mathrm{SiO}_{5}$ TEBC after CMAS corrosion}

Fig. 5 (a) Fig. 5(d) display the cross-section microstructure of $\mathrm{Si} / \mathrm{Y}_{2} \mathrm{SiO}_{5} \mathrm{TEBC}$ corroded by CMAS at $1300^{\circ} \mathrm{C}$ for $30 \mathrm{~min}, 1$ hour, 2.5 hour and 4 hours, respectively. It can be seen from Fig. 5 that there is a dense reaction zone between molten CMAS and $\mathrm{Y}_{2} \mathrm{SiO}_{5}$ top layer no matter how long the reaction continues. The thickness of reaction zone gets larger as the reaction time goes on.
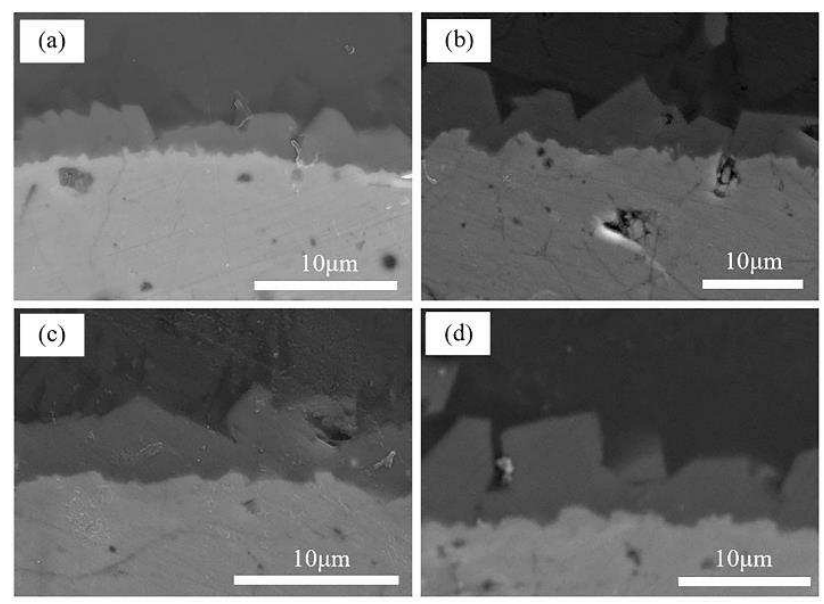

Fig. 5 Cross-section microstructure of $\mathrm{Si} / \mathrm{Y}_{2} \mathrm{SiO}_{5} \mathrm{TEBC}$ corroded by CMAS at $1300{ }^{\circ} \mathrm{C}$ for (a) $30 \mathrm{~min}$, (b) $1 \mathrm{~h}$, (c) $2.5 \mathrm{~h}$, (d) $4 \mathrm{~h}$

Fig. 6 displays the EDS linear scan result of the cross section of $\mathrm{Si} / \mathrm{Y}_{2} \mathrm{SiO}_{5} \mathrm{TEBC}$ 
after 4 hours' CMAS corrosion. There is no doubt that melted CMAS is rich in $\mathrm{Ca}$, $\mathrm{Mg}, \mathrm{Al}, \mathrm{Si}$ and almost no $\mathrm{Y}$ can be detected. The reaction zone is also rich in $\mathrm{Ca}$ and Si. But the proportions of $\mathrm{Mg}$ and $\mathrm{Al}$ dramatically drop in reaction zone. There is a slightly increase of the amount of $\mathrm{Y}$ in reaction zone. In $\mathrm{Y}_{2} \mathrm{SiO}_{5}$ layer, the amount of $\mathrm{Y}$ rapidly increases but the amount of $\mathrm{Ca}$ decreases obviously. The amount of $\mathrm{Si}$ also decreases to a certain degree in $\mathrm{Y}_{2} \mathrm{SiO}_{5}$ layer.

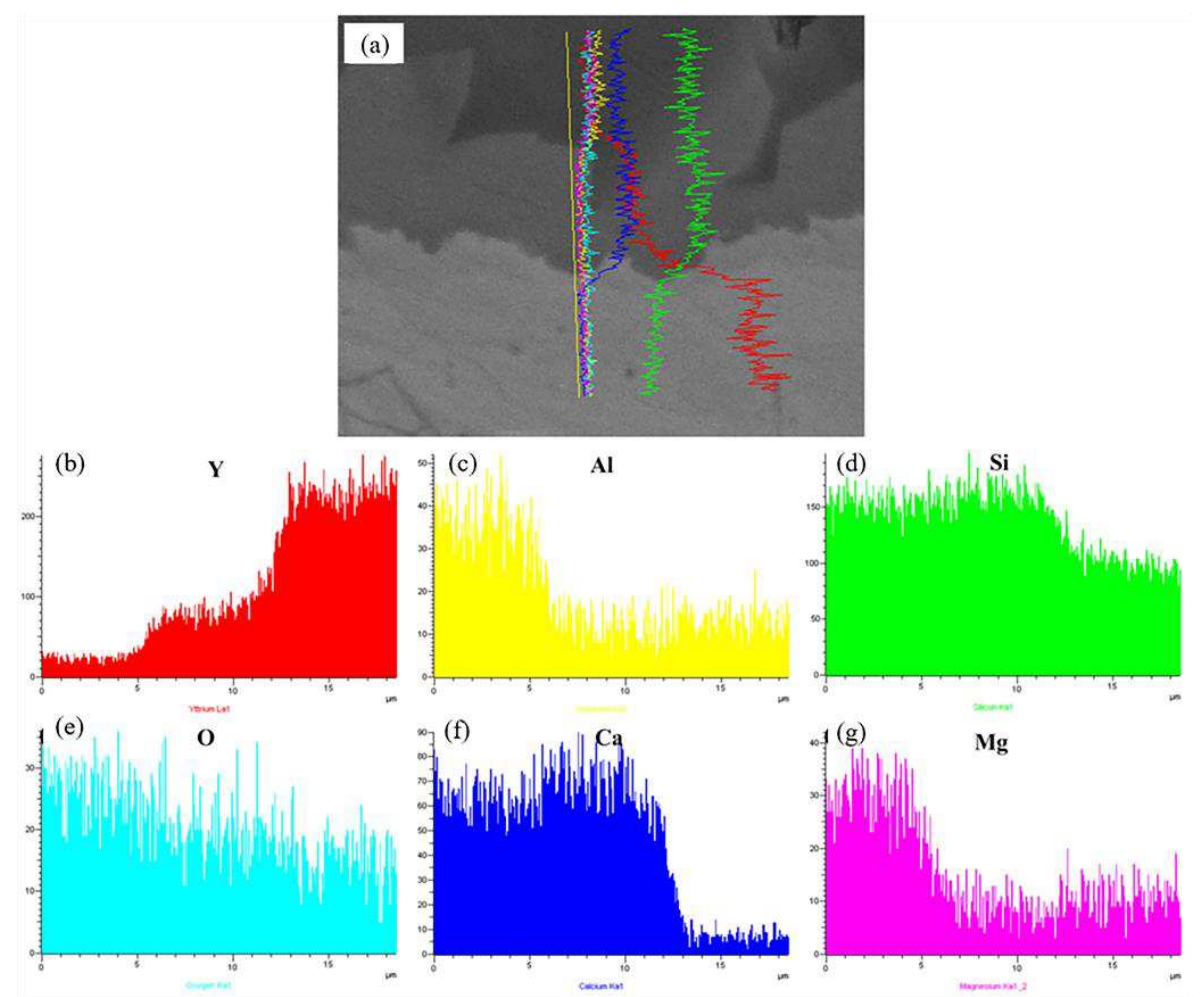

Fig. 6 EDS linear scan results of cross-section of $\mathrm{Si}_{2} \mathrm{Y}_{2} \mathrm{SiO}_{5} \mathrm{TEBC}$ after CMAS corrosion at $1300{ }^{\circ} \mathrm{C}$ for $4 \mathrm{~h}$ (a) overall scanning result, (b) Y, (c) Al, (d) Si, (e) O, (f) $\mathrm{Ca},(\mathrm{g}) \mathrm{Mg}$

It can be summarized from the variation of element proportion shown in Fig. 6 that $\mathrm{Ca}$ and $\mathrm{Si}$ in CMAS continuously permeate into $\mathrm{Y}_{2} \mathrm{SiO}_{5}$, leading to the formation of reaction zone between melted CMAS and $\mathrm{Y}_{2} \mathrm{SiO}_{5}$. And this reaction zone can effectively stop the mutual diffusion of elements in CMAS and $\mathrm{Y}_{2} \mathrm{SiO}_{5}$. So, $\mathrm{Y}$ is not capable to diffuse into the reaction zone and CMAS layer and $\mathrm{Mg}$ and $\mathrm{Al}$ only be 
detected in CMAS layer.

Fig. 7 displays the phase composition of the mixture of $\mathrm{Y}_{2} \mathrm{SiO}_{5}$ and CMAS powders as a weight ratio of $1: 1$ after heating at $1300^{\circ} \mathrm{C}$ for $30 \mathrm{~min}$ and 4 hours, respectively. It can be seen from Fig. 7 (a) that after corroding for $30 \mathrm{~min}$ at $1300{ }^{\circ} \mathrm{C}$, $\mathrm{Y}_{4.67}\left(\mathrm{SiO}_{4}\right)_{3} \mathrm{O}$ and $\mathrm{Ca}_{3} \mathrm{Y}_{2}\left(\mathrm{Si}_{3} \mathrm{O}_{9}\right)_{2}$ can be detected from the mixture of CMAS and $\mathrm{Y}_{2} \mathrm{SiO}_{5}$ powders. The content of $\mathrm{Y}_{4.67}\left(\mathrm{SiO}_{4}\right)_{3} \mathrm{O}$ is higher than $\mathrm{Ca}_{3} \mathrm{Y}_{2}\left(\mathrm{Si}_{3} \mathrm{O}_{9}\right)_{2}$. At the beginning of CMAS corrosion test, part of $\mathrm{SiO}_{2}$ in CMAS react with $\mathrm{Y}_{2} \mathrm{O}_{3}$ in $\mathrm{Y}_{2} \mathrm{SiO}_{5}$, leading to the formation of $\mathrm{Y}_{4.67}\left(\mathrm{SiO}_{4}\right)_{3} \mathrm{O}$. Besides, the remaining $\mathrm{SiO}_{2}$ and $\mathrm{CaO}$ in CMAS react with $\mathrm{Y}_{2} \mathrm{SiO}_{5}$ to form a small number of $\mathrm{Ca}_{3} \mathrm{Y}_{2}\left(\mathrm{Si}_{3} \mathrm{O}_{9}\right)_{2}$. The reaction equation mentioned above are described as follows:

$$
\begin{aligned}
2.335 \mathrm{Y}_{2} \mathrm{O}_{3}(\mathrm{~s})+3 \mathrm{SiO}_{2} & \rightarrow \mathrm{Y}_{4.67}\left(\mathrm{SiO}_{4}\right)_{3} \mathrm{O} \\
3 \mathrm{CaO}+5 \mathrm{SiO}_{2}+\mathrm{Y}_{2} \mathrm{SiO}_{5} & \rightarrow \mathrm{Ca}_{3} \mathrm{Y}_{2}\left(\mathrm{Si}_{3} \mathrm{O}_{9}\right)_{2}
\end{aligned}
$$

When mixture of CMAS and $\mathrm{Y}_{2} \mathrm{SiO}_{5}$ powders is kept at $1300{ }^{\circ} \mathrm{C}$ for 4 hours, a large quantity of $\mathrm{Ca}_{4} \mathrm{Y}_{6} \mathrm{O}\left(\mathrm{SiO}_{4}\right)_{6}$ and small amount of $\mathrm{Ca}_{3} \mathrm{Y}_{2}\left(\mathrm{Si}_{3} \mathrm{O}_{9}\right)_{2}$ are created as shown in Fig. 7. As reaction time is prolonged, large amount of $\mathrm{CaO}$ and $\mathrm{SiO}_{2}$ are consumed. The remaining small amount of $\mathrm{CaO}$ and $\mathrm{SiO}_{2}$ react with $\mathrm{Y}_{2} \mathrm{SiO}_{5}$ to form the $\mathrm{Ca}_{4} \mathrm{Y}_{6} \mathrm{O}\left(\mathrm{SiO}_{4}\right)_{6}$. The reaction equation is described as follow:

$$
4 \mathrm{CaO}+3 \mathrm{SiO}_{2}+3 \mathrm{Y}_{2} \mathrm{SiO}_{5} \rightarrow \mathrm{Ca}_{4} \mathrm{Y}_{6} \mathrm{O}\left(\mathrm{SiO}_{4}\right)_{6}
$$

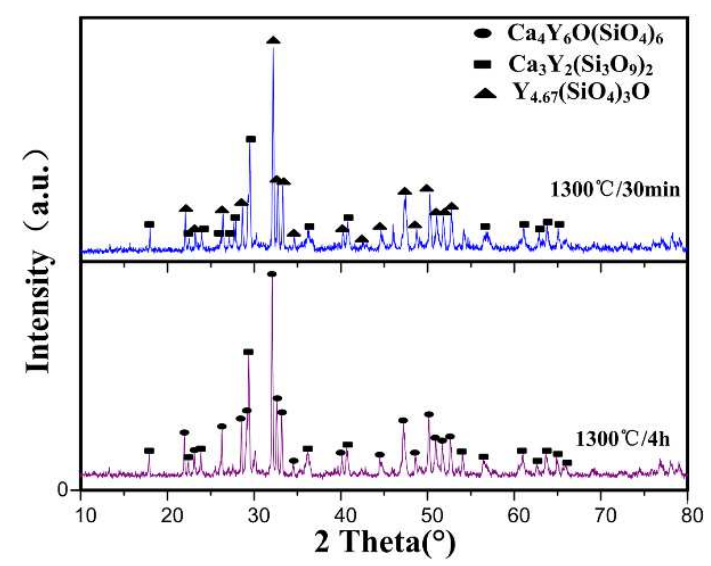

Fig. 7 Phase composition of the mixture of $\mathrm{Y}_{2} \mathrm{SiO}_{5}$ and CMAS powders 
after keeping at $1300{ }^{\circ} \mathrm{C}$ for (a) $30 \mathrm{~min}$ and (b) $4 \mathrm{~h}$

\subsection{Reaction kinetics between CMAS and $\mathrm{Si} / \mathrm{Y}_{2} \mathrm{SiO}_{5}$ coatings}

Table 2 lists the thickness of reaction zone when $\mathrm{Si} / \mathrm{Y}_{2} \mathrm{SiO}_{5} \mathrm{TEBC}$ were corroded at $1200{ }^{\circ} \mathrm{C}, 1250^{\circ} \mathrm{C}$ and $1300{ }^{\circ} \mathrm{C}$ for different times. It can be found from Table 2 that at the same reaction temperature, as reaction time is prolonged, the reaction zone gets thicker. The thickness of reaction zone also increases with reaction temperature when corrosion time is same.

Table 2 The thickness of reaction zone formed with different corrosion temperature and time.

\begin{tabular}{lccc}
\hline \multirow{2}{*}{ Reaction time, $\min$} & \multicolumn{3}{c}{ Thickness of reaction zone, $\mu \mathrm{m}$} \\
\cline { 2 - 4 } & $1200^{\circ} \mathrm{C}$ & $1250^{\circ} \mathrm{C}$ & $1300^{\circ} \mathrm{C}$ \\
\hline 15 & 0.238 & 0.575 & 2.31 \\
90 & 0.31 & 1.239 & 3.66 \\
150 & 0.36 & 1.529 & 4.31 \\
240 & 0.4 & & 5.15 \\
\hline
\end{tabular}

Fig. 8 plots the thickness of reaction zone as a function of square root of oxidation time. Growth of the reaction zone seems to obey the parabolic law:

$$
\mathrm{y}=\mathrm{kt}^{1 / 2}+\mathrm{b}
$$

Where $\mathrm{y}$ is the thickness of reaction zone, $\mathrm{t}$ is the oxidation time, $\mathrm{k}$ is the reaction rate constant, $\mathrm{b}$ is constant. Fitting process is conducted on thickness data listed in Table 2. According to the fitting result, the reaction rate constant at $1200^{\circ} \mathrm{C}, 1250^{\circ} \mathrm{C}$ and $1300{ }^{\circ} \mathrm{C}$ are $0.1466 \mu \mathrm{mh}^{-1 / 2}, 0.8425 \mu \mathrm{mh}^{-1 / 2}$ and $1.9963 \mu \mathrm{mh}^{-1 / 2}$, respectively. The reaction rate constant represents the growth rate of reaction zone at different temperature. When CMAS corrosion test is conducted at $1200^{\circ} \mathrm{C}$, the growth rate of 
reaction zone is very slow. As reaction temperature raising to $1250{ }^{\circ} \mathrm{C}$, the growth rate of reaction zone increases more than four-fold compare with that at $1200{ }^{\circ} \mathrm{C}$. When corrosion temperature continues to raise to $1300^{\circ} \mathrm{C}$, thickness of reaction zone will dramatically increase more than twelve-fold compare with that at $1200{ }^{\circ} \mathrm{C}$.

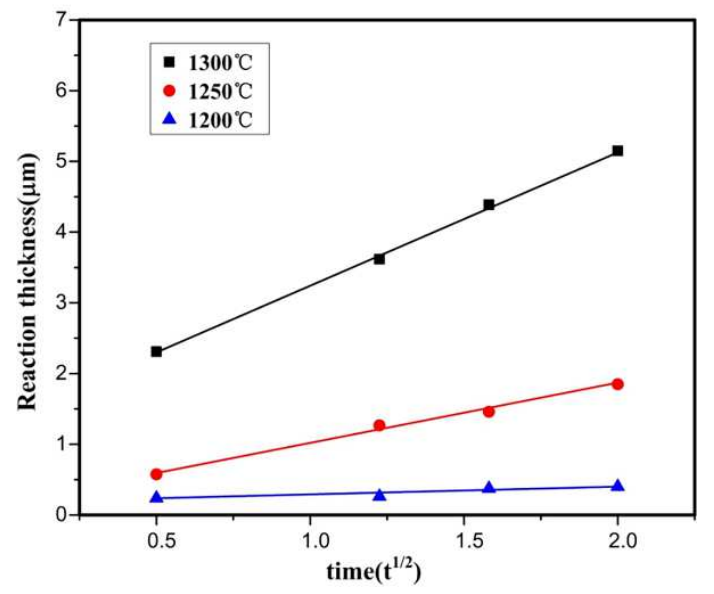

Fig. 8 Thickness of reaction zone as a function of square root of oxidation time

The obtained reaction rate constants at elevated temperature are plotted in Fig. 9. The apparent activation energy for the reaction between CMAS and $\mathrm{Y}_{2} \mathrm{SiO}_{5}$ layer can be calculated using Arrhenius formula as follow:

$$
\mathrm{k}=\mathrm{k}_{0} \exp (-\mathrm{E} / 2 \mathrm{RT})
$$

Where $\mathrm{E}$ is apparent activation energy for CMAS corrosion test, $\mathrm{R}$ is the ideal gas constant, T is temperature of CMAS corrosion test.

The natural logarithm of equation 5 is shown as follow:

$$
\ln \mathrm{k}-\ln \mathrm{k}_{0}=-\mathrm{E} / 2 \mathrm{RT}
$$

According to the fitting result shown in Fig. 9, the relationship between the natural logarithm of reaction rate constant and reciprocal temperature obeys linear relation. The slope of fitting line represents the apparent activation energy for CMAS corrosion, which is calculated to be $713.749 \mathrm{k} \mathrm{J} / \mathrm{mol}$. 


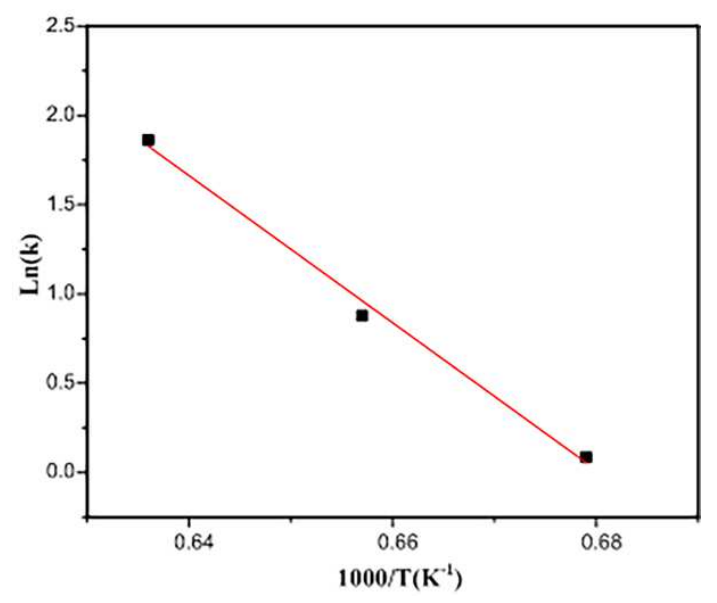

Fig. 9 Natural logarithm of reaction rate constant as a function of the inverse of temperature

\section{Conclusions}

$\mathrm{Si} / \mathrm{Y}_{2} \mathrm{SiO}_{5}$ coated $\mathrm{SiC}_{\mathrm{f}} / \mathrm{SiC}$ were corroded by high temperature water vapor and CMAS in this research. The $\mathrm{Si} / \mathrm{Y}_{2} \mathrm{SiO}_{5}$ TEBC can effectively separate $\mathrm{SiC}_{\mathrm{f}} / \mathrm{SiC}$ substrate from water vapor at $1300{ }^{\circ} \mathrm{C}$ for over 205 hours. After 250 hours' water vapor corrosion, the majority of $\mathrm{Y}_{2} \mathrm{SiO}_{5}$ have transformed into $\mathrm{Y}_{4.67}\left(\mathrm{SiO}_{4}\right)_{3} \mathrm{O}$ because of the reaction between $\mathrm{Y}_{2} \mathrm{SiO}_{5}$ and TGO. With the influence of TGO and cracks caused by stress, part of $\mathrm{Y}_{2} \mathrm{SiO}_{5}$ top layer peels off along the $\mathrm{TGO}$, causing the failure of $\mathrm{Si} / \mathrm{Y}_{2} \mathrm{SiO}_{5}$ TEBC. The melted CMAS permeates into the $\mathrm{Y}_{2} \mathrm{SiO}_{5}$ top layer, leading to the formation of $\mathrm{Ca}_{4} \mathrm{Y}_{6} \mathrm{O}\left(\mathrm{SiO}_{4}\right)_{6}$ and $\mathrm{Ca}_{3} \mathrm{Y}_{2}\left(\mathrm{Si}_{3} \mathrm{O}_{9}\right)_{2}$ in reaction zone ultimately. The $\mathrm{Y}_{4.67}\left(\mathrm{SiO}_{4}\right)_{3} \mathrm{O}$ is intermediates as test is executed at high temperature. The apparent activation energy of reaction between CMAS and $\mathrm{Y}_{2} \mathrm{SiO}_{5}$ is calculated to be $713.749 \mathrm{k}$ $\mathrm{J} / \mathrm{mol}$, which can be used to predict the reaction degree of CMAS corroding $\mathrm{Y}_{2} \mathrm{SiO}_{5}$ when corrosion temperature in the $1200 \sim 1300{ }^{\circ} \mathrm{C}$ temperature range. Overall, the findings obtained from this research are beneficial for screening the appropriate materials used for TEBC to protect Si-based CMC from high temperature water vapor 
and CMAS corrosion.

\section{References}

[1] B.T. Richards, H.N.G. Wadley, Plasma spray deposition of tri-layer environmental barrier coatings, J. Eur. Ceram. Soc. 34 (2014) 3069-3083.

http://doi.org/10.1016/j.jeurceramsoc.2014.04.027.

[2] N. Rohbeck, P. Morrell, P. Xiao, Degradation of ytterbium disilicate environmental barrier coatings in high temperature steam atmosphere, J. Eur. Ceram. Soc. 39 (2019) 3153-3163. http://doi.org/10.1016/j.jeurceramsoc.2019.04.034.

[3] E.N. Dayi, N. Al Nasiri, Diffusion study of rare-earth oxides into silica layer for environmental barrier coating applications, J. Eur. Ceram. Soc. 39 (2019) 4216-4222. http://doi.org/10.1016/j.jeurceramsoc.2019.05.026.

[4] S. Fujii, A. Ioki, T. Yokoi, Role of phonons on phase stabilization of $\mathrm{RE}_{2} \mathrm{Si}_{2} \mathrm{O}_{7}$ over wide temperature range $(\mathrm{RE}=\mathrm{Yb}, \mathrm{Gd})$, J. Eur. Ceram. Soc. 40 (2020) 780-788. http://doi.org/10.1016/j.jeurceramsoc.2019.10.060.

[5] A.V. Plyasunov, A.S. Zyubin, T.S. Zyubina, Thermodynamic properties of $\mathrm{Si}(\mathrm{OH})_{4}(\mathrm{~g})$ based on combined experimental and quantum chemistry data, J. Am. Ceram. Soc. 101 (2018) 4921-4926. http://doi.org/10.1111/jace.15922.

[6] B.T. Richards, K.A. Young, F. de Francqueville, Response of ytterbium disilicatesilicon environmental barrier coatings to thermal cycling in water vapor, Acta Mater. 106 (2016) 1-14. http://doi.org/10.1016/j.actamat.2015.12.053.

[7] K.N. Lee, D.S. Fox, N.P. Bansal, Rare earth silicate environmental barrier coatings for $\mathrm{SiC} / \mathrm{SiC}$ composites and $\mathrm{Si}_{3} \mathrm{~N}_{4}$ ceramics, J. Eur. Ceram. Soc. 25 (2005) 1705-1715. http://doi.org/10.1016/j.jeurceramsoc.2004.12.013.

[8] A.J. Fernández-Carrión, M. Allix, A.I. Becerro, Thermal expansion of rare-earth pyrosilicates, J. Am. Ceram. Soc. 96 (2013) 2298-2305. 
http://doi.org/10.1111/jace.12388.

[9] Z. Tian, L. Zheng, W. Jiemin, Theoretical and experimental determination of the major thermo-mechanical properties of $\mathrm{RE}_{2} \mathrm{SiO}_{5}(\mathrm{RE}=\mathrm{Tb}, \mathrm{Dy}, \mathrm{Ho}, \mathrm{Er}, \mathrm{Tm}, \mathrm{Yb}, \mathrm{Lu}$, and Y) for environmental and thermal barrier coating, J. Eur. Ceram. Soc. 36 (201) 189202. http://doi.org/10.1016/j.jeurceramsoc.2015.09.013.

[10] Z. Sun, J. Wang, M. Li, Mechanical properties and damage tolerance of $\mathrm{Y}_{2} \mathrm{SiO}_{5}$, J. Eur. Ceram. Soc. 28 (2008) 2895-2901.

http://doi.org/10.1016/j.jeurceramsoc.2008.04.029.

[11] Z. Sun, M. Li, Y. Zhou, Thermal properties of single-phase $\mathrm{Y}_{2} \mathrm{SiO}_{5}$, J. Eur.

Ceram. Soc. 29 (2009) 551-557. http://doi.org/10.1016/j.jeurceramsoc.2008.07.026.

[12] Y. Ogura, M. Kondo, T. Morimoto, Oxygen permeability of $\mathrm{Y}_{2} \mathrm{SiO}_{5}$, Mater. Trans. 42 (2001) 1124-1130. http://doi.org/10.2320/matertrans.42.1124.

[13] J. Han, Y. Wang, R. Liu, Study on water vapor corrosion resistance of rare earth monosilicates $\mathrm{RE}_{2} \mathrm{SiO}_{5}(\mathrm{RE}=\mathrm{Lu}, \mathrm{Yb}, \mathrm{Tm}, \mathrm{Er}, \mathrm{Ho}, \mathrm{Dy}, \mathrm{Y}$, and $\mathrm{Sc})$ from first-principles calculations, Heliyon. 4 (2018) e00857. http://doi.org/10.1016/j.heliyon.2018.e00857. [14] B. Ywa, A. Yn, Z.A. Xin, Water vapor corrosion behaviors of plasma sprayed $\mathrm{RE}_{2} \mathrm{SiO}_{5}(\mathrm{RE}=\mathrm{Gd}, \mathrm{Y}, \mathrm{Er})$ coatings, Corros. Sci. 167 (2020) http://doi.org/10.1016/j.corsci.2020.108529.

[15] N. Al Nasiri, N. Patra, D.D. Jayaseelan, Water vapour corrosion of rare earth monosilicates for environmental barrier coating application, Ceram. Int. 43 (2017) 7393-7400. http://doi.org/10.1016/j.ceramint.2017.02.123.

[16] Z. Tian, C. Lin, L. Zheng, Defect-mediated multiple-enhancement of phonon scattering and decrement of thermal conductivity in $\left(\mathrm{Y}_{\mathrm{x}} \mathrm{Yb}_{1-\mathrm{x}}\right)_{2} \mathrm{SiO}_{5}$ solid solution, Acta Mater. 144 (2018) 292-304. http://doi.org/10.1016/j.actamat.2017.10.064.

[17] B.K. Jang, F.J. Feng, K.S. Lee, Thermal behavior and mechanical properties of 
$\mathrm{Y}_{2} \mathrm{SiO}_{5}$ environmental barrier coatings after isothermal heat treatment, Surf. Coat. Tech. (2016) 24-30. http://doi.org/10.1016/j.surfcoat.2016.09.088.

[18] Z. Tian, X. Ren, Y. Lei, Corrosion of $\mathrm{RE}_{2} \mathrm{Si}_{2} \mathrm{O}_{7}(\mathrm{RE}=\mathrm{Y}, \mathrm{Yb}$, and $\mathrm{Lu})$ environmental barrier coating materials by molten calcium-magnesium-aluminosilicate glass at high temperatures, J. Eur. Ceram. Soc. 39 (2019) 4245-4254. http://doi.org/10.1016/j.jeurceramsoc.2019.05.036.

[19] E. Garcia, H. Lee, S. Sampath, Phase and microstructure evolution in plasma sprayed $\mathrm{Yb}_{2} \mathrm{Si}_{2} \mathrm{O}_{7}$ coatings, J. Eur. Ceram. Soc. 39 (2019) 1477-1486.

http://doi.org/10.1016/j.jeurceramsoc.2018.11.018.

[20] Z. Tian, L. Zheng, W. Hu, Tunable properties of $\left(\mathrm{Ho}_{\mathrm{x}} \mathrm{Y}_{1-\mathrm{x}}\right)_{2} \mathrm{SiO}_{5}$ as damage selfmonitoring environmental/thermal barrier coating candidates, Sci. Rep.-UK. 9 (2019) http://doi.org/10.1038/s41598-018-36883-2.

[21] L. Liu, W. Zheng, Z. Ma, Study on water corrosion behavior of $\mathrm{ZrSiO}_{4}$ materials, J. Adv. Ceram. 7 (2018) 336-342. http://doi.org/10.1007/s40145-018-0283-3. 